\title{
Family, Reproduction and Religious Ethos in Brazil
}

Subjectivism and naturalism as structuring values

Luiz F. D. Duarte, Juliana de M. Jabor, Edlaine C. Gomes et Naara Luna

\section{(2) OpenEdition}

Journals

Édition électronique

URL : http://journals.openedition.org/assr/14303

DOI : $10.4000 /$ assr. 14303

ISSN : $1777-5825$

Éditeur

Éditions de l'EHESS

Édition imprimée

Date de publication : 1 juin 2008

ISBN : 978-2-7132-2190-3

ISSN : 0335-5985

Référence électronique

Luiz F. D. Duarte, Juliana de M. Jabor, Edlaine C. Gomes et Naara Luna, «Family, Reproduction and Religious Ethos in Brazil », Archives de sciences sociales des religions [En ligne], 142 | avril-juin 2008, mis en ligne le 13 décembre 2010, consulté le 03 mai 2019. URL : http://journals.openedition.org/ assr/14303 ; DOl : 10.4000/assr.14303 


\section{Luiz F. D. Duarte, Juliana de M. Jabor, Edlaine C. Gomes, Naara Luna Family, Reproduction and Religious Ethos in Brazil
Subjectivism and naturalism as structuring values}

In a recent work, we presented the hypothesis that it is the ethical disposition adopted by social subjects in modern liberal societies that tends to push them towards particular religious choices, or to a subjective questioning of the guidelines of their ascribed religion, or indeed the desire to live without any attachment to a formal religious institution-and not the other way round (Duarte, 2005). In the process, we pointed towards the existence of: (1) a private nondenominational, lay and generalized ethos, which includes-but is not confined to-various aspects of the individualist ideology shaping the modern liberal order and pervading the different segments of Brazilian society; (2) a differentiated incorporation in contemporary Christian doctrines of various dimensions of the values associated with this individualist "modern" ideology and its private behavioural corollaries.

This hypothesis directly affects current reflections on the influence of religious belonging on the definition of private behaviour and the very conception of what should be considered as "religious" in the modern world. Our approach advocates the need to comprehend the "religious" in modern societies not from a linear nominalist perspective, but in the wide sense of a "worldview", a structuring cosmology, recognizing that today the space of "religiosity" covers many officially "lay"-or at least, "non-denominational"-values and behaviours (Duarte, 1983: 58).

Our aim in the present work is to examine how the private ethical dispositions typical of the new conditions of affirming religious belief operate in Brazilian society and in what way they are related to the encompassing nondenominational ideological lines of force typical of the modern liberal public order. Here we look to systematize the ethnographic information available in the literature in light of the data from research recently conducted by the authors ${ }^{1}$.

1. The project "Family, Reproduction and Religious Ethos" funded by the Ford Foundation and CNPq (in the latter case, as part of the project "Sexuality, Gender and Family: ruptures and continuities in the experience of the modern Western Person" coordinated by Luiz F. D. Duarte). 
Our hypothesis is that the configuration of the new religious forms is somehow connected with the permanent, though irregular, diffusion of modern cosmology in contemporary societies through the formal and productive diffusion of structuring "institutionalizations" that have affected even the lower social classes: the rationalization, egalitarianization and liberalization of public space. We shall directly examine the contemporary action of a bundle of ideological lines of force that we believe to be entwined within a dense and complex historical interaction. Here we use the term "modern cosmology" to refer to the set of these lines of forces. The structuring values described here as a "subjectivism" and a "naturalism" look to explicate the empirical motifs present in the literature and the ethnographic material, while simultaneously developing a dialogue with the theoretical models available for interpreting the phenomena characteristic of modern Western culture.

\section{Subjectivism}

The reference to "subjectivism" looks to emphasize the pre-eminence of the idea of the subject's personal choice, a presumed elementary individual freedom prevalent in the field of religious experience today. Danièle Hervieu-Léger shows how this process currently unfolding in contemporary France is associated with a "modern culture of the individual" (1993: 142), involving an "individual right to subjectivity" (1993: 143). The expression "ethical individualism" present in the literature on religion in contemporary Brazil (Machado 1996: 20, for example) and clearly linked to the theme of the "ideology of individualism" indicates the broader ideological implications of this characteristic phenomenon of modern Western culture. The qualification "ethical" in the formula refers both to the Weberian tradition with its emphasis on the association of modern rationality with a disenchanted ethos, and to the Durkheimian tradition with its emphasis on modern universalization.

Subjectivism is undoubtedly an important ideological property of the contemporary religious field. However, it also involves a more immediate sociological dimension, since the value of freedom of choice is coupled with the legal and practical possibility of actualizing this value under certain specific conditions. Clearly the issue goes beyond simply relativizing the idea of autonomy intrinsic to this field of values by appeal to the presumed sociological determination of human behaviour. Instead it involves taking this idea seriously as a factor shaping many of the properties of concrete actions. On the other hand, we cannot ignore that the idea of a condition of religious freedom, undoubtedly generalized, is counterbalanced by the native, enchanted experience of subjection to religious commandments-particularly during periods of intense adherence.

By suggesting that subjectivism seems to be an ever more pervasive aspect of religious attitudes across all denominations, we not only wish to highlight 
a generic subjectivism underlying the process of choice, hesitation and interreligious transition, but also this other, more specific subjectivism of maintaining a private life relatively independent of religious dictates, even during periods of intense adherence. Both the research material and the literature abound in examples of personal interpretations of religious mandates, even in Catholicism where canonical strictness is more explicit and intense. Particularly conspicuous examples in Brazil include Lucia Ribeiro's work (1994) on reproductive decision-making among Catholic religious activists at variance with ecclesiastical mandates, and the work of Marcelo Natividade (2003) on young gay people who maintain a tense relationship with Pentecostalism. This process is certainly at the root of the increasingly widespread appeal of the Protestant churches and their favouring of an ethical disposition of immediate personal interpretation of the sacred text (at least in comparison with the Catholic emphasis on the exclusivity of institutional mediation), combined with leaving the decision on various sensitive aspects of private ethos to individual judgment. Although personal interpretation can occur in any church where the congregation is not strictly controlled, there is always a psychological pressure involved in contravening dogmas or precepts.

The area of sexuality/reproduction is particularly sensitive to this subjectivist emphasis, which also indirectly affects the areas of family and gender identity. The diffusion of this schema is particularly challenging and pressing among the lower social classes, since the shifts in ethos are tending irresistibly towards a combination with modern hegemonic values, in large part due to the fundamentally external position occupied by the culture of these classes and by the growing pressure exerted on them to change and "modernize".

A generalized hedonist ethic can be considered to be an integral part of these liberal values. Above all, this includes the privileging of the satisfaction or pleasure to be obtained in this world in the form of personal emotional fulfilment. These values are described in the contemporary literature as comprising a direct part of the horizon of religious experiences ${ }^{2}$. This point is particularly notable in terms of its distance from Christianity's widely recognized and analyzed traditional emphasis on suffering. Weber systematized the idea of "thisworldliness" (Diesweltlichkeit) as a defining feature of modern Christian religiosity, subsequently developed in Louis Dumont's analyses of the passage from the "individualoutside-the-world" to the "individual-in-the-world" typical, he argues, to modern Western individualism (Dumont, 1983). Marshall Sahlins and Colin Campbell later explained with great perspicacity and detail the connections between secularization and hedonism (Campbell, 1995; Sahlins, 1996) now dominating our cultural horizon.

2. On personal satisfaction and the affirmation of self in the contemporary religious context, see, for example, Hervieu-Léger, 1993: 142, 145; Csordas, 1997: 25; or Machado, 1996: 23. 
A wide-ranging research study conducted by ISER on evangelism in Rio de Janeiro (Fernandes et al., 1998) showed that recognition of sex as a "source of happiness" oscillates in a range of between $40 \%$ and $60 \%$ of informants from different Pentecostal denominations (compared to "necessary sacrifice" and "biological necessity"). Lucia Ribeiro records and analyzes the "awareness of the importance of having your own space and the power to "live life" among militant Catholics from Grassroots Church Communities (CEBs) in relation to contraceptives (1994: 157).

The recognition of this subjectivism as a dimension of modern religiosity is a basic principle of the sociology of religion. As mentioned above, the Weberian theme of secularization and ethicization involves the description of a modern religious universe in which the motor of religious experience becomes centred within the subject. Durkheim (1968) was also fairly unequivocal on the modern tendencies of religion, which he explicitly dubs a "cult of the self". William James (1958) produced a perfect demonstration of this process in his classic work dedicated precisely to religious "experience" describing the way in which social subjects "subjectively" experience this dimension of social life. More recent authors such as Peter Berger (1970) and Marcel Gauchet (1985) returned to the theme, deepening the diagnosis of the subjectivism prevalent in the modern experience of religion. Paul Heelas (1991) went as far as to describe what he called religions of the self in the contemporary world. All these analyses emphasize the intrinsic relationship between this process and the specificity of the Christian tradition, which became critical-in modernity-through Protestantism. The central and shared points undoubtedly comprise the ethical disposition towards truth (personal responsibility for the correctness of acts in the world), the conviction in free will (autonomy of personal will), and the recognition of an interiorization (as the seat of a free conscience).

\section{Naturalism}

The second point we propose to comprise an important element of this diffuse modern cosmology can be called a "naturalism". As is well-known the category of nature is crucial to the ordination of modern cosmology, under different guises and through different traditions of knowledge (Gusdorf, 1972; Schlanger, 1971; Descola \& Palsson, 1996). Clearly this involves a new and radical evaluation of the physical reality of the world, capable of being apprehended by the human reason (itself seen as natural) and opposed to the traditional Christian preeminence of the supernatural and moral transcendence. This idea was expressed in various aspects of the early modern ideology. The most immediate and practical aspect was, since the outset, the possibility given to the emergence of the idea of modern science. In terms of morality, it suffices to evoke the importance of the representations of an original "natural state" of humanity (whatever the 
characteristics attributed to this state), a "natural right" intrinsic to all human societies and prevailing over all historically localized positive rights, a "natural light" characteristic of subjective consciousness, and even a "natural religion" as an expression of a universal feeling underlying the actually existing religious forms (Giumbelli, 2002: 30). A fundamental step in the establishment of this new cultural horizon was the application of this schema to human beings themselves, in the redefinition of the relationship between body and soul (Le Breton, 1988) and the construction of a new framework of intelligibility of their presence in the world.

The enlightenment and scientificist representation of nature was developed and sublimated by Romanticism-especially in the form of the value of life (Gusdorf, 1972, 1985; Thomas, 1983; Duarte, 2004), assuming the main characteristics through which it became presented and diffused as a structuring "belief" of the West (prior to any dogma or religious precept). The Catholic Church itself, committed in principle to resisting the invasion of modern values, ended up helping to reinforce this ideological point by invoking "naturalist" arguments in its defence of limits to individualist values. This was particularly notable in the idea, for example, that the family model (specifically Western-modern) defended today is a natural value (see the references to natural right ever since the dawn of modern ideology in Luna, 2002).

A clear demonstration of the pre-eminence of the nature value in modern ideology is provided by Marilyn Strathern (1992) in her discussion of ideas of family and kinship in the Anglo-Saxon part of the world in the last quarter of the $20^{\text {th }}$ century. This is certainly one of the fields most directly affected by our cosmovision. One of the points of this private ethos where nature stands out in contemporary ethnographic information is that of abortion (in which it is held to be directly threatened, under the aspect of life). The perception of the cosmological quality of this value certainly contributes to shedding light on the difficulties that surround the understanding of the declarations and acts concerning abortion in the modern world (see the "ambivalence" on this topic recognized among Brazilian Protestants cited in Fernandes et al., 1998: 111). As Cecília Mariz aptly notes in analyzing precisely this data, "all the indications are that the religious variable is important, but it is not the only variable that affects this type of opinion. Perhaps religion is not the most important" (Mariz, 1998: 221). This likewise matches the information provided by Ribeiro on militant Catholics and their attitudes on abortion (Ribeiro, 1994: 163). An interesting interpretation in this case centres on the confrontation between subjectivism and naturalism, insofar as a disposition in favour of abortion can often be deduced from an attitude emphasizing the autonomy of a woman's decisions concerning her own body (and her control over bodily pleasure and aesthetics), while a resistance to abortion may arise-as indeed does actually arise in the pronouncements of informants from all kinds of religious affiliations-from a generic respect for life or nature (Luna, 2004: 305). 


\section{8 - ARCHIVES DE SCIENCES SOCIALES DES RELIGIONS}

Although, as we have seen, there is a considerable literature on the historical construction and sociological presence of naturalism as an ideology, there does not seem to be any established tradition of comparing this set of values and religiosity. Following the path of common sense, this ideology seems to be too close to science to allow its consideration as a religious trace or dimension. Even authors that have focused on demonstrating the culturally constructed character of scientific facts do not go as far as to equate the belief in scientific truth with the belief in natural reality underlying religious belief systems. When religion is compared with the modern scientific universe, it is invariably to disqualify it, precisely by demonstrating its non-scientificity.

\section{Religious tenets as "justifications" for private choices}

The lines of force of modern cosmology have a predominant influence on the organization of the private ethos due to their high degree of public legitimacy and their unquestioned, structuring condition-a genuine "common sense" increasingly absorbed by all levels of society through the dominant channels of ideological diffusion (school, communications media, interaction with professional and activist mediators, and so on). The main difference between these two ideological sectors is that "religious" discourses-insofar as they differ, in the modern world, in terms of their pastoral contents and are indeed forced to make this difference explicit-also tend to appear divided into a "market" of religious options theoretically open to personal choice; modern ideology, on the other hand, by being overwhelmingly dominant, fluid and non-controversial (apart from the technical dimensions of its formulas, inaccessible to its lay consumers) can appear to the public as a stable and incontestable dimension (and, for this reason, less explicit in terms of its "cosmologicalness" so to speak). In effect, the traditional relationship between the encompassing religious cosmology and the sporadic and encompassed lay speculations is inverted: the lay speculations take the form of an encompassing ideology, while the old encompassing cosmology becomes fragmented into religious "speculations".

This is why we risk stating that, in such a context, the religious messages relating to behavioural control or "private ethos" seem to function for social subjects more as "justifications" (paradoxical, because unconscious) of their personal adherences; whether in the form of a substitution/alternation of religious affiliation in the direction of one more suited to the chosen lifestyle, or in the form of a occasional questioning or disobedience of the precepts of an already assumed religion. Hence we propose that contemporary adherence to religious institutional dogma and experiences tend to consist of a religious justification (in the sense of an a posteriori "rationalization") of deeper and more widespread cosmological dispositions whose explanations are found in the lay ideology of modernity. This hypothesis applies especially to the area of private ethos, which 
the social regulations of liberal societies tend to leave open to individual decision (with some exceptions) and which is thus submitted to more malleable, intimate and sometimes secret regimes of justification. However, the coexistence of a wide variety of highly legitimized or generalized moral conventions designed to regulate this private ethos with the ideology of choice and interior decisionmaking seems to lead many social subjects towards the standardized institutional formulas offered by the different denominations (or by some of their internal sectors).

Our hypothesis does not deny the enormous importance of the doctrinal and pastoral guidelines of these denominations in influencing the private behaviour of the population involved, nor does it deny that these guidelines interfere in the processes of permanence or change now under way-especially for the considerable sections of the population that remain in their attributed or original communities of belief. As research in Brazil has shown over the last few decades, a crucial dimension of the dynamic of modern societies is the existence of religious institutions capable of providing justification for the many behavioural alternatives arising from the complex and non-linear diffusion of modern values, as well as other religious institutions specialized in organizing the more or less systematic resistance to these values (or of combining the two tendencies in an original way).

Demonstrating the pregnancy of subjectivism in direct ethnographic experiences is no simple task. This is not due to the absence of signs of the phenomenonwhich are indeed abundant. In fact the difficulty is rooted precisely in its ubiquity and high degree of spontaneity, as well as the banal, everyday manner in which it is manifested. This ideological feature is not found in the form of a wellorganized native theory; on the contrary, it surfaces as a generalized common sense premise, whose spontaneous emergence makes it difficult to distinguish from the overall flow of discourse. In this sense, it is not a topic capable of being pursued in interviews. It is the concrete cases-the life stories, the immediate material of the discourse on experience-that furnish the palpable and registrable proof of its presence as a value.

As mentioned earlier, we can distinguish two active levels of subjectivism within the domain of explicit religiosity. The first level is the high degree of personal or individual choice involved in actual religious practice or in a posteriori recollection. The second is the cultivation of a reserve of doubt within a condition of wider belonging. Both the first and second levels contain a supplementary dimension whose explicitness varies: namely, a particular emphasis on the personal "satisfaction" to be gained through the use of one option or another. We already underlined its presence earlier as an hedonism within subjectivism.

Our research material covers very different social conditions among the lower, middle and upper classes. Subjectivism is more predominant in the upper 
segments, in direct correlation with their tradition of an instituting adherence to individualist ideology. In most of the material relating to these segments, any religious experience tends to be very literally a secondary effect of the "cult of self" and its use would be almost tautological in terms of our line of argument. As a result, we shall focus only on those cases in this ethnographic universe that are closer to the explicitly religious field.

The first of these cases involves a family from the middle class of Rio de Janeiro's South Zone, already in its third generation in the Baptist Church. The native valorization of choice is expressed here in complementary and concomitant form with the rejection of any idea of religious family heritage (Jabor, 2005). Individual religious affiliation-which marks the process of conversion from the outset and which culminates with late baptism-is experienced by the subject as a new birth. The role performed by this subjective dynamic is fundamental: it is up to the inner will of the individual subject to take the first step towards its truth and its salvation. The words of Luiza-a second generation Baptist, married, the mother of three children, 50 years old and an economist-express extremely well the valorization of this individual choice in opposition to family ascription: "God has no grandchildren, God only has children. The fact that you're a child of a child of God doesn't connect you to this family, this spiritual family."

This emphasis, associated with the intense concern over the intergenerational transmission of the religious ethos, produces a very particular tension in the education of the new generations, entreated to reproduce the family tradition, but to do so through acquisition rather than ascription-that is, through inner subjective affiliation rather than traditional conformism. This presents us with a contemporary example of the tension between Church and Sect classically proposed by Weber: while the former encompasses formal belonging, the latter is typified by the continual expectation of intimate personal adherence. In this sense, subjectivism prevails in the Protestant tradition, as can be seen in the native discourse cited earlier, affirming individual choice and rejecting familyreligious traditionalism.

On the other hand, as a clear example of an immediate relation between religious institutional choice and the definition of private ethos we can take the case of Socorro, a 40 year old woman, married, the mother of two children, and Luiza's work colleague. In contrast to Luiza, Socorro does not come from a Protestant family. Catholic by birth, Socorro went in search of spiritual help at a difficult moment of her life. Pregnant, Socorro was at risk of losing the baby. She tried frequenting the Baptist Church but says that she was unable to adapt. She started searching for other churches but nothing seemed to satisfy her. Socorro's ideal church had to meet various requirements: 1 . a short distance to walk from the bus stop to her house and to the church door; 2. a small church where all the "brothers and sisters" knew each other; 3 . the presence of charismatic gifts, especially the gift of tongues, but without "all that shouting, like at 
the Assembly of God"; 4. absence of a preacher passing round "the little hat collecting money", or else her husband, who she wanted to take to the church, would say she was "keeping the minister fed."

Socorro's choice of the church most "suited" to her needs and dispositions perfectly illustrates this individualizing perspective, which can almost be equated with an utilitarianism. Although very different to her own experience, Luiza recognizes the experience of her friend Socorro when she declares: "The choice of Church has a lot to do with the person's way of being, especially nowadays."

Laura is a fairly elderly working class woman with nineteen grandchildren, a former midwife and curer (mixing Catholicism and umbanda). Her speech makes frequent reference to nature and its relationship to both profane and sacred life. It was Laura who declared to one of the authors during another research period: "Nobody can go against nature, only God" (Duarte, 1986: 279). Having spent her whole life dealing with the phenomena of life and illness from a position authorized both by her connections to religion (at no moment in her discourse does she suggest any feeling of contradiction between her intense participation in the activities of the local Catholic church and in an umbanda terreiro) and by her connections to medicine (since she took part in technical training in obstetrics under the direction of one of Rio de Janeiro's top doctors in the 1940s), Laura frequently reflects on the critical situations in which she was involved. Among her numerous accounts of difficult pregnancies and births, there are a few cases in which the decision to abort arose, especially in order to save the mother's life. Her discomforts on the topic were never related to the sphere of the sacred (or, more specifically, Catholic doctrine, for example); they rather involved doubts about the meaning of the "natural" in humans, above all in situations in which the survival of both mother and child seems in doubt. Her admiration always centres on the force of nature (or life) evident in these cases and on the need to match therapeutically her own physical and spiritual force with the encompassing natural force, so as to achieve the best possible outcome. In such cases, her moral and religious positions invariably take second place to her veneration for the predominance of the value of life. This was always heavily stressed in the frequent cases of risky attempts to abort: the intensity of human will and the violence of the means employed are always matched by a kind of insurrection of life claiming its rights.

The daughter of separated parents, coming from a non-practicing Catholic family, although she studied from an early age in a Catholic college, Ana converted when she was fourteen years old to the Seventh-Day Adventist Church, remaining in this same religious institution to the present day, now aged thirtyfour. She has practiced sports since childhood, from swimming to ballet. She excludes meat from her diet though this is not a usual practice in her family. Her process of conversion was not the result of some kind of "affliction". Ana's interest in Adventism stemmed precisely from the stance adopted by the Church 
in relation to health and the body, concerns that were present before her conversion. The Adventist Church's ideas met her expectations and needs. Her aim was to discover how to unite what for her were two equally important dimensions: a private non-religious ethos (as in the case of the diet-body-health interrelationship) and an institutional religious experience-or a religious ethos, in other words. It was only when she realized that such a combination was possible in this particular Church that she went ahead with her decision to join.

Here, in the case of a younger female informant from the working class, subjectivism is strongly marked. Dietary prescriptions are commonly practiced by members of this Church: however, these are not qualified as doctrines but comprise attitudes to be incorporated in order to achieve the necessary equilibrium between the physical, mental and spiritual, amounting to a preparation for the "new land". Here we are dealing with "individual salvation" in its more traditional Reformation sense.

An important source of information on private ethos and its relation to religiosity is the research by Naara Luna on new reproductive technologies (Luna, 2002, 2004). The conditions through which she obtained her material-through interviews, particularly with female patients in a medical-hospital contextprovide a useful counterpoint to the material of other authors, obtained in interviews conducted in a domestic context. The informants encountered in this area typically combine an intense desire to overcome the physical barrier of sterility with the willingness to do so by resorting to biomedicine. This very fact underlines a wider dimension of emphasis on human will, expressed in the technological capacity to "repair" nature itself, a possibility frequently represented as an alliance with divine will. One female informant declared: "Do it for yourself and I'll help you."

We can take the concrete example of Adelina, a member of the Assembly of God (a Pentecostal church), who, after learning that her surgery to reverse a tubal ligation was unsuccessful, was unsure whether she should trust in God or "carry out the treatment by the hand of men" that is, resort to in vitro fertilization to try to become pregnant. She did not plan to talk to the preacher or tell anyone else in her church if and when she decided to resort to assisted reproduction since, according to her, the Assembly of God was an extremely strict church and she would be censured. Paraphrasing biblical passages, she said that God creates things that do not exist. She says that God had told her in her dreams and through vessels (the prophets of the "house of the Lord") that her heart's desire would be fulfilled that year. She asked several trusted sisters to pray for her and requested a secret prayer (oração em oculto), receiving the laying on of hands. They asked her whether her biggest desire was the (religious) "liberation" of her husband. She replied: "No, it's [to have] my child, because a child is for your whole life, while a husband might not be." 
In these cases the disposition to follow "the heart's desire" is strong enough to confront the recommendations of the religions to which people belong-as we have already seen in the previous example. In some cases, this confrontation takes an omissive form; in others, a commissive form, with the denunciation of religious precepts, yet with the person continuing to belong to the church. Finally, a third alternative involves the change in religious affiliation in pursuit of an institutional welcoming of the person's subjective disposition. These individual dispositions clearly follow the contrasting lines of the different religious organizations on the market, sometimes involving a relativization of the canonical precepts by the religious leaders themselves.

Cristiane, a user of assisted reproduction provided by the public health service, was baptized and married in the Catholic Church, but also frequented an umbanda centre when the physical cause of her infertility was diagnosed and she was sent for in vitro fertilization treatment. The priestess (mãe-de-santo) purportedly told her: "if I was you, I would go for an adoption and not... not try [the treatment]." (...) "She meant that if God wanted, I would become pregnant." Cristiane stopped going to the terreiro as she felt the people there were stifling her subjective choices: "It meant leaving my life in someone else's hands and I didn't think that was a good thing." Cristiane began to question the guidance she had received and rejected the idea of the divine it contained. Instead, she followed her own interpretation, according to which, since God allows the existence of the technique, using it cannot be to act against God's will. She began to see God as someone who was helping her intimate disposition and not as someone who prohibits or limits.

The pre-eminence of will, desire, the capacity for personal choice has a complex relationship with the theme of the pre-eminence of nature. Nowadays human intervention, led by science (in this case, medical science), enables choices that are impossible under natural conditions. Asked by a friend whether having children with medical help in the form of in vitro fertilization was different, Cristiane said about her reproductive disposition: "If it isn't possible one way, it will be another way." A certain enchantment over this alliance of human will with scientific and technological capacities is expressed in explicit form in the words of Mariana, a non-practicing Catholic, who celebrated the success of her assisted reproduction treatment: "... how man can intervene in the nature of things... It's crazy to think science was able to help even me!"

Although the theme of naturalism is already implicated, therefore, in the material on subjectivism, given their persistent empirical relations, we turn now to a more detailed discussion of this other theme, allowing us to anchor the observed manifestations in more concrete terms.

From the outset, we need to keep in mind three broader points that underwrite the ideas concerning the ways in which nature is supposed to structure human behaviour. The first point is the relation between naturalism and the 
authority of scientific descriptions of reality that are seldom questioned. Medical decisions or suggestions may occasionally be criticized or rejected, but not the veracity or authenticity of diagnoses and judgments. This relationship built on scientific authority is continually mingled with the relation to an omniscient and omnipotent divinity, producing a complex web of interconnections between personal will, divine will and natural determination.

The second broad point is the complexity of the notion of "life" in play in this field of meanings. The connections between native representations of nature and life are non-linear, meaning careful interpretation is required of the prevalent emphasis on categories such as "human life," "living being" or "natural process".

Finally it is worth highlighting the importance of the interconnections between the idea of biological inheritance via blood-simultaneously a natural substance and the essence of kinship-and categories such as "genetic material" and "pregnancy". All three are typically physical-moral insofar as they emphasize the combination or juxtaposition of the natural dimension and the socialrelational dimension.

Statements in which the faith in divinity is associated with trust in medical care are fairly common and do not represent exceptions, even in the discourse of medics. For example, in her interaction with users, a female doctor from a public university medical institution stresses that medics are not God, meaning they have to investigate in order to intervene in concrete physical situations. An informant commented on her own chances of becoming pregnant: "Only God knows-and the doctors." Divine action and human action (scientifically led) are implicitly or explicitly allied in the words of a significant proportion of patients and doctors. Many of these women undergoing infertility treatment question the discourse pronounced by their chosen religions urging acceptance of their condition. One of them repeated this type of discourse in a deprecating tone: "people say it's because God doesn't want it, it's not the right time." By contrast, she believes that God is already helping her.

The belief in medical science is, in fact, a specific corollary of a more widespread belief in an "objective reality," a natural order of the world, a law of life, whose determinant immanence coexists with divine will in a complex way. This naturalism works very well in affirming subjectivism, allowing a degree of leeway amenable to personal interpretation.

Sometimes the idea also surfaces of human technological intervention as a threat to the "natural" conditions of reproduction, making human relations artificial, commercialized and mechanized. In these cases, this "denaturalization" also seems to correspond to a distancing from divinity, which confirmsnegatively-the correlation perceived earlier between these two cosmological 
dimensions. A Protestant informant receiving treatment in a university fertility clinic preferred to undergo a surgery to reverse her tubal ligation rather than trying in vitro fertilization to get pregnant, because "it's safer to be natural".

\section{God, nature, life, choice \& satisfaction}

The last point to underline is, as mentioned, the idea of a biological inheritance as one dimension of an encompassing naturalism. In terms of human reproduction, this idea is connected with the topics of genetic material and pregnancy.

Edna, a Protestant from a traditional denomination who received assisted reproduction treatment in a specialized private clinic, declared herself favourable to the use of technologies as long as they do not go against God's teachings. When asked if she would object to in vitro fertilization on the basis of her religious values, she replied no, as long as they used "all the eggs" and did not donate them. She stated her opposition to the donation of gametes on religious grounds.

Here we can see how naturalism functions as a structuring value in such disparate personal situations, although always linked to other cosmological dimensions. In turning to focus specifically on naturalism's relations to subjectivism, we should consider the recurrent intertwining of the three wills: divine, natural and human (or subjective). The first point to stress is the tendency to refer divine will to a superior level (including to the level of specific religious proclamations) by means of distinct mental constructions. The main of these is the search for a positive correlation between the three wills, in which divine will prevails as a kind of trump card. Whenever this correlation is found to be absent, it is because God's will was stronger than human dispositions, whether in terms of personal will or scientific and technological capacities. This can take place in indirect form through the refraction of the divine in human faith. Any positive correlation, on the other hand, is likewise indirectly attributed to the divine.

The status of belief in science, as part of a supposed cosmological emphasis on nature, is a topic that demands further investigation. Does this belief effectively involve the "science" of scientists-that is, the system of scholarly knowledge complexly instituted in our culture from the $17^{\text {th }}$ century onwards-or another cultural entity in which the idea of technological intervention in the world prevails over lay knowledge of a radically immanent reality? Even if-as seems to be the case-it involves something approaching the second hypothesis, the idea in question bears a close relation to what we have referred to as naturalism. Indeed, as we have seen, even those responsible for the biomedical version of scientific knowledge in Brazil tend to present (at least in the particularly dramatic context of assisted reproduction) ideas of reality that include some kind of explicit "supernaturalness". 
The ethnographic data pointing to the rejection of abortion as an attack on the sacred character of life-a rejection which can be found in a highly generalized and polemical form in various sectors of modern societies-can be associated with a prevalence of the value of nature over the value of subjectivity in less individualizing social groups and classes, as we hypothesized earlier. The other pole is dominated by the figure of the mother as an autonomous individual, managing the use of her own body and sexuality. However, based on the material presented here, subjectivism can also be seen to prevail from the viewpoint of the unborn child, represented as a person from the point of conception onwards, when the "cellular" material begins to constitute a "living being". In this case we are faced with an overlapping-rather than a contradiction-between subjectivism and naturalism: human nature, manifest in the elementary form of human life, is effectively coextensive with the elementary autonomy of the subject. This would explain the frequent construal of the incipient embryo (as soon as composed by fertilization, even in vitro) as a foetus, as a child and as a son or daughter.

In this case, the condition of "son or daughter" is particularly representative of this condition of full person, already possessing an instituting and unavoidable relational bond. As one female informant said: "whether you want it or not, it's your child." This provides us with an important ethnographic element when it comes to relocating the question of subjectivism within a cultural context little permeated with the ideology of individualism. Subjectivization involves autonomization and relational connection at one and the same time.

On the other hand, our ethnographic material also reveals the presence, even among the lower social classes, of a more subjectivist disposition based on the freedom to carry out abortions in the name of individual responsibility and personal "satisfaction" through the realization of a personal life project (Mariz, 1998: 221).

As we noted, the multiform ethnographic material highlighting the preeminence of subjectivism and naturalism in the constitution of the contemporary private ethos does not lessen the importance of comprehending the ecclesiastical dispositions on this domain. Equally multiform, it is these dispositions that appear to our informants as the alternatives in which the values suited to their dynamic insertion in the modern world are materialized and reflected. Furthermore, as we were able to evoke, they are themselves traversed by the reference to the "modern" ideas of individual freedom and the underlying natural reality.

Although we cannot develop the point in more detail here, it should be emphasized that the contemporary presence of the subjectivism analyzed here can in some ways be associated with the continuing vigour of the disposition to comprehend liberty, choice and individual autonomy as the affirmation of a subjective relation with the cosmos, rather than as the monadic autarchy found in the liberal model (described by Georg Simmel as a "quantitative individualism"). This continuing presence is not explained by sympathetic magic, but by 
palpable processes of cultural diffusion and transformation. A crucial turning point was the counter-culture of the $1960 \mathrm{~s}$ and its singular transposition of Romantic values that had until then distinguished the enlightened, cultured members of the European elites (and their peripheral transpositions) to a mass movement. The literature on the new religious configurations in the European world, for example, clearly demonstrates how these forms directly depend on this diffusion, as Danièle Hervieu-Léger explicitly acknowledges (1993: 146). This is the way through which the literate segments of modern Western societies ended up multiplying the feelings of solidarity with totality (lost), subjectivity (threatened), flow (staunched), the sensible (wilted), the body (rationalized) and nature (stained)-the constellation of values essential to the New Age phenomenon and the revival of the sacred in the metropolitan world. Here we find a subjectivism and a naturalism clearly characterized by the confluence of historical necessity and sociological evidence.

The counter-cultural turn should be seen as the point of mutation when the subordinate legitimacy of the Romantic attitude gave way to the possibility of openly questioning-and at a mass level-the universalist horizon. What had been until then the privilege of the happy few, especially in the domain of art and the techniques of inner selfhood, came to permeate all mass communication and all daily life with a growing legitimacy of sensoriality (experience), worldly satisfaction (consumerism), bodily performance (hedonism) and induced states of extreme intensity (drugs, religious ecstasy, radical sports and so on). This is the world of self-fulfilment cited by Hervieu-Léger (1993: 142): radical subjectivism; radical naturalism.

The phenomena analyzed here-currently emergent in Brazilian society-have direct relations with this metropolitan world due to the instituting and continuing relations of the country's elites and middle classes with the central dynamic of modern Western culture. However this panorama is compounded by a considerable complementary complexity, deriving from the cultural dynamic of the other, lower class segments, only formally subordinated to individualism's horizon of legitimacy. It happens, though, that the lines of force of this other cultural dynamic-more hierarchical or holistic, as Duarte has proposed (1986)-are structurally similar to the Romantic positions in terms of privileging the moral embeddedness of bodily and sensorial experiences, by ensuring the pre-eminence of experiential and physical-moral totality of the phenomena of human satisfaction and perturbation, and by demanding the relational dependence of attitudes and choices. A subjectivism and naturalism too, albeit by other means, today coexisting and dialoguing with what filters down from the elites increasingly further and deeper into society. In short, a fertile horizon of cultural forms, full of new possibilities for structuring values.

The full comprehension of so-called religious phenomena in our modern societies can only advance by including non-religious, presumedly lay, values 
I 28 - ARChives DE SCIENCES SOCIALES DES RELIGIONS

on the analytic horizon, which mould and colour the contemporary symbolic "structures of plausibility." The task is far from simple, since it demands that the localized ethnographic investments-which are absolutely essential-are periodically combined into more ambitious analytic proposals capable of advancing along the fecund paths of anthropological comparison. As we lack any automatic privilege of analytic distance, it is only with much resolve and method that we can succeed in glimpsing the larger contours of the cultural nebula that constitutes us and that lends meaning to our beliefs and goals.

Luiz F. D. Duarte, Juliana de M. Jabor, Edlaine C. Gomes, Naara Luna Museu Nacional, Universidade Federal do Rio de Janeiro lfdduarte@uol.com.br

\section{Bibliography}

BERGER Peter, 1970, A Rumor of Angels. Modern society and the Rediscovery of the Supernatural, New York, Anchor Books.

Campbell Colin, 1995, The Romantic Ethic and the Spirit of Modern Consumerism, Oxford, Blackwell.

Csordas Thomas J., 1997, The Sacred Self: a Cultural Phenomenology of Charismatic Healing, Berkeley, University of California Press.

Descola Philippe, Pálsson Gisli, (eds.), 1996, Nature and Society: Anthropological Perspectives, London, Routledge.

DuARTE Luiz F. D., 1983, "Pluralidade Religiosa nas Sociedades Complexas e 'Religiosidade' das Classes Trabalhadoras Urbanas”, Boletim do Museu Nacional (Nova Série - Antropologia), 41, pp. 1-69.

-, 1986, Da Vida Nervosa (nas classes trabalhadoras urbanas), Rio de Janeiro, Jorge Zahar Editor/CNPq.

-, 2004, "A Pulsão Romântica e as Ciências Humanas no Ocidente », Revista Brasileira de Ciências Sociais, 19 (55), pp. 5-18.

-, 2005, "Ethos privado e racionalização religiosa. Negociações da reprodução na sociedade brasileira ", in Heilborn M. L., Duarte L. F. D., Lins de Barros M., Peixoto C., (éds.), Relações Familiares, Sexualidade e Religião, Rio de Janeiro, Garamond, pp. 137-176.

Dumont Louis, 1983, Essais sur l'individualisme. Une perspective anthropologique sur l'idéologie moderne, Paris, Seuil.

DuRкнеiм Émile, 1968 [1912], Les formes élémentaires de la vie religieuse, Paris, Presses universitaires de France.

FERnANDes Rubem C. et al., 1998, Novo Nascimento. Os evangélicos em casa, na igreja e na política, Rio de Janeiro, Mauad.

GAUCHET Marcel, 1985, Le désenchantement du monde. Une histoire politique de la religion, Paris, Gallimard.

Giumbelli Emerson A., 2002, O Fim da Religião: dilemas da "liberdade religiosa " no Brasil e na França, Rio de Janeiro, CNPq/Pronex /Attar Editorial. 
Gusdorf Georges, 1972, Dieu, la Nature, l'Homme, au siècle des lumières, Paris, Payot. -, 1985, Le savoir romantique de la Nature, Paris, Payot.

HeElas Paul, 1991, "Reforming of the Self: Enterprise and the Characters of the Thatcherism”, in Keat R., Abercrombie N., (eds.), Enterprise Culture, London, Routledge \& Kegan Paul.

Hervieu-LÉger Danièle, 1993, "Present-day Emotional Renewals: The End of Secularization or the End of Religion?”, in Swatos W., (éd.) A Future for Religion? New Paradigms for Social Analysis, London, Sage, pp. 129-148.

Jabor Juliana de M., 2005, Do amor ético: Um estudo sobre pessoa e família entre batistas, Master's Dissertation, Rio de Janeiro, Universidade Federal.

JAMES William 1958 [1902], The Varieties of Religious Experience. A Study in Human Nature, The New American Library.

LE BRETON David, 1988, «Dualisme et Renaissance. Aux sources d'une représentation moderne du corps ", Diogène, 142, pp. 42-63.

LUNA Naara, 2002, "As novas tecnologias reprodutivas e o estatuto do embrião: Um discurso do magistério da Igreja Católica sobre a natureza ", Revista Gênero, 3-1, pp. $83-100$.

-, 2004, Provetas e Clones: Teorias da Concepção, Pessoa e Parentesco nas Novas Tecnologias Reprodutivas, Doctoral Thesis, Rio de Janeiro, Universidade Federal do Rio de Janeiro.

Machado Maria das Dores C., 1996, Carismáticos e pentecostais. Adesão religiosa na esfera familiar, Campinas, Editora Autores Associados/ANPOCS.

MAriz Cecília L., 1998, "A opinião dos evangélicos sobre o aborto (discussão sobre alguns dados da pesquisa "O Novo Nascimento") ", in Fernandes R. C. et al. (eds.), Novo Nascimento. Os evangélicos em casa, na igreja e na política, Rio de Janeiro, Mauad, pp. 211-223.

Natividade Marcelo T., 2003, Carreiras homossexuais e pentecostalismo: análise de biografias, Master's Dissertation, Rio de Janeiro, Universidade do Estado.

Ribeiro Lúcia, 1994, "Anticoncepção e Comunidades Eclesiais de Base », in Costa A. O., Amado T. ? (éds.), Alternativas Escassas. Saúde, Sexualidade e Reprodução na América Latina, Rio de Janeiro, Editora 34 - Editora Nova Fronteira, pp. 143-174.

SAHLINS Marshal, 1996, "The sadness of sweetness - the Native Anthropology of Western Cosmology”, Current Anthropology, 37, pp. 395-415.

SChlanger Judith, 1971, Les métaphores de l'organisme, Paris, Vrin.

STRATHern Marilyn, 1992, After Nature: English Kinship in the Late Twentieth Century, Cambridge, Cambridge University Press.

Thomas Keith, 1983, Man and the Natural World, Harmondworth, Penguin Books. 
I 30 - ARCHIVES DE SCIENCES SOCIALES DES RELIGIONS

\section{Résumé}

Il s'agit d'examiner et d'approfondir l'bypothèse selon laquelle non seulement les valeurs laïques, non confessionnelles, de la liberté individuelle (choix, subjectivité, autonomie) et de la nature (vie, sang, science) constituent le noyau cosmologique des sociétés occidentales, comme elles sont critiques pour la définition de l'ethos privé (virginité, contraception, avortement, homosexualité), même dans les situations où l'appartenance à des religions qui suivent des valeurs contraires ou alternatives semble constituer la dimension cruciale de l'identité sociale. Même la formule canonique de ces valeurs dans chaque église semble dépendre fondamentalement du rapport aux valeurs de la liberté et de la nature. Les auteurs s'appuient sur des données de recherche de terrain originale et récente.

Mots-clés : Famille, reproduction, religion, sexualité, nature.

\section{Abstract}

Based on primary ethnographic research conducted by its authors, this article aims to deepen the hypothesis that contemporary Western societies are not only pervaded by lay, non-denominational, structuring values such as those of individual "freedom" (choice, subjectivity, autonomy, etc.) and "nature" (life, blood, science) but that they play a crucial role in defining key aspects of private ethos (virginity, abortion and homosexuality) and thereby encompass not only the alternatives pursued by the doctrinal and pastoral guidelines of specific religions, but also the differing dispositions of religious adherence found among social subjects.

Key words: Family, Reproduction, Religion, Sexuality, Nature.

\section{Resumen}

El presente artículo trata de examinar y de profundizar la hipótesis según la cual no sólo los valores laicos, no confesionales, de la libertad individual (elección, subjetividad, autonomía) y de la naturaleza (vida, sangre, ciencia) constituyen el nudo cosmológico de las sociedades occidentales, sino también son críticos para la definición del ethos privado (virginidad, contracepción, aborto, homosexualidad), hasta en las situaciones en las cuales la pertenencia a religiones que siguen valores contrarios o alternativos parece constituir la dimensión crucial de la identidad social. Incluso la fórmula canónica de estos valores en cada iglesia parece depender fundamentalmente de la relación a los valores de la libertad y de la naturaleza. Los autores se apoyan en datos surgidos de trabajo de campo original y reciente.

Palabras clave: Familia, reproducción, religión, sexualidad, naturaleza. 